\title{
Effect of polyherbal galactogogue supplementation on milk yield and quality as well as general health of Surti buffaloes of south Gujarat
}

\author{
M. D. Patel, K. K. Tyagi, L. M. Sorathiya and A. B. Fulsoundar \\ Livestock Research Station, \\ Navsari Agricultural University, Navsari-396 450, Gujarat-396 450, India \\ Corresponding author: M. D. Patel, email: drmanish911@yahoo.com \\ Received: 15-08-2012, Accepted: 12-09-2012, Published online: 30-01-2013
}

How to cite this article: Patel MD, Tyagi KK, Sorathiya LM and Fulsoundar AB (2013) Effect of polyherbal galactogogue supplementation on milk yield and quality as well as general health of Surti buffaloes of south Gujarat, Vet. World 6(4):214218, doi: 10.5455/vetworld.2013.214-218

\begin{abstract}
Aim: A polyherbal galactogogue based on indigenous knowledge of tribles (Bhagats) belonging to Patalkot (Madhya Pradesh), Dangs (Gujarat) and Aravallis (Rajasthan) was evaluated on lactating Surti buffaloes (medium sized buffalo breed of South Gujarat which is best suitable for small and marginal farmers as well as landless labourers/tribal with less input resources).

Materials and Methods: A total of 22 lactating Surti buffaloes maintained at Livestock Research Station, Navsari Agricultural University, Gujarat, India were randomly allotted to treatment and control group (11 buffaloes in each group). Two polyherbal galactogogue biscuits (19 $\mathrm{g}$ each) per day for initial 10 days of the month over a period of three months were supplemented to buffaloes in treatment group. The daily milk yield of all 22 buffaloes was recorded. Milk samples from all experimental buffaloes at fortnight interval were analyzed on automatic milk analyzer. The pooled gain/loss of BCS in all the buffaloes was worked out. DMI (\%) were also worked out by averaging all fortnight observations.

Results: A significant higher $(p<0.05)$ total milk yield $(14.24 \%)$ of treatment group was recorded. The effect of polyherbal galactogogue biscuits was non-significant on milk compositions. Dry matter intake $/ 100 \mathrm{~kg}$ body weight (DMI \%) was found significantly $(p<0.01)$ better in treatment over control. The buffaloes of treatment group had lost significantly $(p<0.01)$ lesser body condition scoring (BCS) than control however, both groups had lost BCS from initial BCS. The net profit of treatment was Rs.339.90/animal/month higher than control and calculated cost-benefit ratio of treatment and control groups was 1:1.62 and 1:1.52 respectively.
\end{abstract}

Conclusion: It was concluded that supplementary feeding of polyherbal galactogogue to lactating Surti buffaloes is cost effectively beneficial for milk yield and general health condition.

Keywords: body condition scoring, DMI, milk yield, net return, poly herbal galactogogue, surti buffaloes

\section{Introduction}

Optimal milk production is the basic requirement in the management of dairy economics. As a highly demanding period, transition can be affected by many factors that could compromise the health, productivity and reproductive performance of dairy animals. Nutritional strategies can be used to prevent metabolic diseases in the early days post-calving and to increase milk production. A wide variety of additional feed additives exist that may also have potential for use over a few weeks pre-partum and post-partum. Beyond appropriate feeding management, the administration of some additives such as plant extracts, enzymes, glucose precursors, probiotics, choline and vitamin $\mathrm{E}$ may be helpful in ameliorating nutrient utilization and availability with a consequent improvement of milk yield, milk protein, milk fat and milk somatic cell count. These additives may also improve health status, which implies a decrease of early post-partum diseases and better reproductive performance [1-3].

Galactogogues / lactogogues are medications or other substances believed to assist in the initiation, maintenance, or augmentation of maternal milk production. Keeping in view the preservation of animal health and prevention of excessive stress on its production capacity through hormone and alike, a holistic approach making use of herbal formulations has come up as a desirable approach. Majority of these herbal preparations have however not been thoroughly scientifically evaluated but their traditional use suggested some safety and efficacy [4]. In order to restore the animal productivity and to optimize the milk production in individual animals for better profits, various drugs, herbal preparations, hormones, mineral supplements and feed additives have been tried with variable results [2-11].

Leptadenia reticulata, Asparagus racemosus, Nigella sativa and many more are known for galactogogue effect [12]. Researchers have also reported significant galactopoitic response in various milch animals [3-9, 11-19]. Singhal [9] observed as high as $31.10 \%$ increase in milk yield of Payapro ${ }^{\circledR}$ fed cows, whereas, Qureshi [7] not only observed an increase in milk yield but also an increase in the fat percentage of milk in dairy cows fed with Lectovet $^{\circledast}$ (a herbal combination). Baig and Bhagwat [5] also reported 
improvement in milk yield, CLR, Fat \% and SNF \% on use of Galactin Vet ${ }^{\circledR}$ in dairy cows. Herbal preparations have also been shown to relieve the heat stress in dairy cows and ultimately improve their productivity [20]. Sridhar and Bhagwat [21] also reported significant improvement in heamoglobin, serum calcium and total protein levels after treatment of Galactin $\mathrm{Vet}^{\circledR}$ with $5.48 \%$ increased milk yield which indicates the good health of the animals. Kolte and co-workers [15] also reported that indigenous herbal preparations effectively restored the altered milk constituents and increased the milk production in cows with sub-clinical mastitis. However, Şekerden [22] reported that in milking animals, lactation stage is one of the major factors influencing yield and compositions of milk in buffalo. Whereas, Mech and co-workers [23] found that Total protein, Lactose, SNF and Ash did not vary significantly except fat content of milk on use of herbal preparations in animals.

A polyherbal galactogogue which is a purely herbal and based on indigenous knowledge of tribles (Bhagats) belonging to Patalkot (Madhya Pradesh), Dangs (Gujarat) and Aravallis (Rajasthan) for inducing and maintaining lactation in humans. It includes unique formulation that included various parts of 16 medicinally important plants as listed out in Table-1.

Table-1. Scientific and common names of herbs used in formulation of polyherbal galactogogue

\begin{tabular}{lll}
\hline Sr. No. & Scientific Name & Common Name in India (Gujarat) \\
\hline 1 & Acacia catechu & Khair \\
2 & Acacia nilotica & Desi babul \\
3 & Alstonia scholaris & Saptaparni \\
4 & Anethum graveolens & Suva \\
5 & Aspargus racemosus & Shatavari \\
6 & Coriandrum sativum & Dhania \\
7 & Curnium cymium & Jeera \\
8 & Foeniculum vulgare & Saunf \\
9 & Lepidium sativum & Asalio, Halim \\
10 & Leptadenia reticulata & Dodi \\
11 & Madhuca indica & Mahua \\
12 & Pueraria tuberosa & Phagvel, Khakarvel, Patal kumhra \\
13 & Saccharum officinarum & Ganna \\
14 & Sesamum indicum & Til \\
15 & Tephrosia purpurea & Sarphonka \\
16 & Tinospora cordifolia & Jiwantica \\
\hline
\end{tabular}

The present study had been planned to assess the effect of a polyherbal galactogogue on lactating Surti buffaloes in respect of milk yield, milk compositions and general health status.

\section{Materials and Methods}

Ethical approval: Necessary permission of Institutional animal ethics committee was taken before initiation of experiment.

The present experiment was conducted at the Livestock Research Station, Navsari Agricultural University, Navsari, Gujarat state, India. The duration of this study was 89 days i.e. from 1st February to 30th April, 2011 excluding Initial 10 days that was considered as preliminary period. The experiment was conducted in both sides of pakka animal shed with separate iron experimental stalls for each animal. The experimental animals were tied with GI chain in their respective stalls. The identification number of respective animal was written on the inner upper edge of feeding passage wall just in front of the respective treatment group of animals for convenience in feeding and management.

A total of 22 lactating Surti buffaloes (medium sized buffalo breed of South Gujarat which is best suitable for small and marginal farmers as well as landless labourers/tribal with less input resources) maintained at LRS, NAU, Navsari were selected. They were randomly allotted to treatment and control group (eleven buffaloes in each group). The mean lactation yield of previous month, parity, days in milk and milk compositions did not differ significantly at $p<0.05$ between two groups at the start of experiment. All animals were dewormed in the month of January, 2011 with Liq. Zycloze ${ }^{\circledR}$ (Zydus Pharmaceuticals). All the animals remained always tied except for milking as it was done in milking parlor.

The fodders and feed used in the experiment was paddy straw as dry fodder, lucerne and hybrid napier grass as green fodders and Sumul Dan as concentrate. Fodder crops were cultivated either on the fodder farm of LRS, Navsari or other research farms of NAU at Navsari and Sumul Dan manufactured by co-operative cattle feed factory of Sumul dairy at Chalthan, Surat was purchased. In both groups, the animals were offered balanced ration to fulfill requirements as per ICAR [24] feeding standard. The percent proportion of the daily ration used to feed is given in Table-2. Based on guideline of feeding standard, the proportion of ingredients was calculated in such a way that they provide daily DCP and TDN requirements to all the experimental animals.

A total of eleven Surti buffaloes under treatment group were fed two biscuits of a polyherbal galactogogue orally only in morning (between 8:00 to 9:00 a.m.). Biscuits were fed to each of the buffaloes of treatment group by mixing them into $150 \mathrm{~g}$ of concentrate i.e. Sumul Dan for first 10 consecutive days of the month during the treatment period for 89 days (1st February to 30th April, 2011). Same quantity of Sumul Dan was also been given to each of the buffaloes in control group over and above routine feeding of concentrate at the time of milking to buffaloes of both the groups.

All buffaloes were milked twice a day in milking parlor i.e. morning between 4:00-5:00 a.m. and evening 4:00-5:00 p.m. The milk had been collected after hand milking of each buffalo into a clean and dried stainless steel bucket and was weighed on electronic weighing balance and recorded in daily milk yield register. The milk samples were collected from all experimental buffaloes during morning and evening at fortnight interval. The collected milk samples were analyzed on automatic milk analyzer i.e. Lactoscan Milk Analyzer from Bulgaria. All animals were weighed on weighing balance at the start of the 
Table-2. Percent proportion and proximate compositions of feed ingredients offered (DM basis)

\begin{tabular}{lllllllll}
\hline Sr. No & $\begin{array}{l}\text { Name of Feed } \\
\text { Ingredients }\end{array}$ & Proportion & OM & CP & \multicolumn{2}{c}{ Proximate composition } \\
& & CF & EE & NFE & Ash \\
\hline 1 & Concentrate & 33 & 81.33 & 18.05 & 10.48 & 2.81 & 49.99 & 18.67 \\
2. & Lucerne & 17 & 90.88 & 18.54 & 26.15 & 2.71 & 40.48 & 9.12 \\
3. & Hybrid Napier & 17 & 87.31 & 9.48 & 31.77 & 1.83 & 44.23 & 12.69 \\
4. & Paddy straw & 33 & 81.35 & 6.78 & 29.24 & 2.01 & 43.32 & 18.65 \\
5. & DudhNahar & Only in treatment group & 89.18 & 3.0 & 0.00 & 0.00 & 86.18 & 10.82 \\
& Calculated CP & 12.96\% & & & & & & \\
\hline
\end{tabular}

Table-3. Means of milk yield and compositions in Surti buffaloes influenced by polyherbal galactogogue biscuits

\begin{tabular}{lllcc}
\hline Parameter & Control Group & Treatment Group & Difference & Percent increase over control \\
\hline Total Milk Yield in 89 days (litres) & $364.85 \pm 15.57^{\mathrm{a}}$ & $416.82 \pm 17.16^{\mathrm{b}}$ & 51.97 & 14.24 \\
Milk composition (\%) & $6.34 \pm 0.27$ & $6.55 \pm 0.29$ & - & - \\
Fat & $9.43 \pm 0.20$ & $9.68 \pm 0.23$ & - & - \\
SNF & $3.50 \pm 0.14$ & $3.36 \pm 0.27$ & - & - \\
Protein & $4.90 \pm 0.14$ & $5.09 \pm 0.12$ & -- & -- \\
Lactose & & & - \\
\hline
\end{tabular}

Means differing by superscript in a row are significant $(p<0.05)$

Table-4. Effect of polyherbal galactogogue biscuits on DMI and BCS of Surti buffaloes

\begin{tabular}{lcc}
\hline Parameter & Control Group & Treatment Group \\
\hline DMl kg/d & $11.11^{\mathrm{a}}$ & $11.64^{\mathrm{b}}$ \\
DMl \% & $2.99^{\mathrm{a}}$ & $3.12^{\mathrm{ba}}$ \\
Initial BCS & 3.98 & 3.84 \\
Final BCS & 3.70 & 3.82 \\
Loss in BCS & $-0.28^{\mathrm{a}}$ & $-0.02^{\mathrm{b}}$ \\
\hline
\end{tabular}

Means differing by superscript in a row are significant $(p<0.01)$

experiment. The body condition scoring of buffaloes were recorded by using 1-5 score with increment of 0.25 at first and last day of experiment. The pooled gain/loss of BCS in all the buffaloes was also worked out. The feed and fodders as per the feeding schedule were weighed before feeding and supplied separately to the experimental buffaloes. The DMI \% was calculated by considering initial body weight of animals. The pooled observations pertaining to DMI were worked out by averaging all fortnight observations. Feed cost was calculated based on feed ingredients offered daily. The rates of feed ingredients were taken in to calculation as fixed by Navsari Agricultural University except concentrate and mineral mixtures as their actual purchase price were taken into consideration. Milk yield and cost of feed was calculated on monthly basis. Cost-benefit ratio was calculated based on market value of milk and total feeding cost of the month.

The means of all particular observations were analyzed as per standard statistical procedure using Student t-test described by Snedecor and Cochran [25].

\section{Results and Discussion}

The average milk yield of control and treatment group is given in Table-3. The average milk yield of control group over a period of 89 days was recorded as 364.85 litres, whereas, in treatment group, it was recorded as 416.82 litres with the difference of 51.97 litres. The milk yield of treatment group was found significantly higher than the control group $(p<0.05)$ with $14.24 \%$ higher in average milk yield over control group. Earlier, number of researchers had reported an increase in milk yield from 9.12 to $31.10 \%$ on supplementation of herbal galactogogue preparations [3-9, 13-18, 21]. Anjaria and Gupta [14] reported the significant increase in milk yield of goats, sheep, cows and buffaloes with Leptadenia reticulata. Ramesh and associated [8] also reported net gain in milk yield of 0.819 litres per HF cross-bred cow per day after feeding of Galactin ${ }^{\circledR}$ a polyherbal galactogogue. Further, they found that increased milk yield during the declining phase after peak production of milk was sustained for a minimum period of 3 weeks. The effect of herbal preparations might have helped in optimizing the ruminal fermentation that ultimately increased the nutrient availability for milk production [6]. Dadkhah and Yeganehzad [26] resulted 20-40\% increase in daily milk production in cows due to using the plant extracts (Medicago Sativa, Trigonella Foenum and Carum Carvi). They further found $12-25.2 \%$ and $3-17 \%$ increased levels of prolactin and insulin as well as blood glucose levels, respectively. Increased appetite and noticeable improvement in their general health condition was also observed by them. During the present study, the effect of polyherbal galactogogue biscuits was not observed better as compared to previous reports as Surti buffaloes of LRS were maintained on standard managemental conditions as well as feeding schedule. While it might have better effect at farmer's door step as animal may or may not be on balanced ration and standard managemental conditions.

The means of various milk compositions are given in Table-3. The milk compositions i.e. Fat, SNF and Lactose except protein in treatment group were 
Table-5. Net return and cost-benefit ratio as influenced by supplementation of polyherbal galactogogue biscuits

\begin{tabular}{lcc}
\hline Parameter & Control Group & Treatment Group \\
\hline Feed Cost/animal/month (INR) & 2393.30 & 2393.30 \\
Cost of treatment/month (INR) & - & 180.00 \\
Total feeding cost/animal/month (INR) & 2393.30 & 2573.30 \\
Average milk yield/ animal/month (litres) & 121.61 & 138.94 \\
Market value of milk/animal/month @ INR.30/litre of milk & 3648.30 & 4168.20 \\
Net return over feed cost (INR/animal/month) & 1255.00 & 1594.90 \\
Cost : Benefit ratio over feed cost & $1: 1.52$ & $1: 1.62$ \\
\hline
\end{tabular}

recorded slightly higher than that of control group and means did not differ significantly $(\mathrm{p}<0.05)$ between two groups. The results were in accordance with earlier findings of scientists [5,27-29].

However, contradictory to the results of present study significant effects on the milk compositions on feeding of herbal galactogogues in animals were also reported by the scientists $[13,14,18,30]$.

The mean dry matter intake $(\mathrm{kg} / \mathrm{d})$, DMI \%, gain/loss in body condition scoring (BCS) are given in table- 4 . The mean dry matter intake $(\mathrm{kg} / \mathrm{d})$ and DMI \% was found significantly higher $(p<0.01)$ in buffaloes of treatment group. Earlier, similar results were reported by Kirtikar \& Basu [31] where Ruchmex- a polyherbal preparation acted as good appetizer and stomachic. Gupta and co-workers [32] also reported the significant increase in dry matter intake of crossbred heifers supplemented with A. racemosus. Many herbal preparations increased the salivary secretions, boosted the populations of friendly bacteria and protozoa, optimized the digestive functions and ultimately helped in the assimilation and metabolism of feeds $[6$, 33-35].

Buffaloes selected for the present study were in initial phase of mid lactation at the time of peak yield. Hence, all have lost the BCS as a result of production stress. But, the buffaloes of treatment group have lost less BCS as compared to control group may be due to an efficient microbial digestion enhanced by the feeding of polyherbal galactogogue biscuits.

The calculated costs of feeding, net return over feeding and cost-benefit ratio are given in table-5. The net return over feed cost/animal/month was found higher (INR 1594.90) in treatment group than control (INR 1255.00). The calculated cost-benefit ratio was 1:1.62 in treatment and 1:1.52 in control group. These results were in accordance to findings of scientists $[18$, 36] that herbal galactogogue preparations safely enhance the production and thereby improve dairy economics.

\section{Conclusion}

The results of the present study indicated that supplementary feeding of polyherbal galactogogue biscuits to lactating Surti buffaloes is cost effectively beneficial for milk yield and general health condition. Evaluated polyherbal galactogogue biscuits is nonhormonal and a combination of different herbs which can be considered as safe and cost effective. Therefore, the inclusion of such herbal preparation in dairy animal's diet should be encouraged to improve the efficiency of feed utilization to alleviate adverse effects of environmental stress and to enhance the overall animal performance and health.

\section{Authors' contribution}

MDP: Overall monitoring and implementation of study, data collection, tabulation, drafted and revised the manuscript. KKT: Helped in planning of experiment and carried out the statistical analysis. LMS: provided necessary help for data collection during the study. ABF: Sanctioned necessary permission and provided technical guidance as and when required. All authors read and approved the final manuscript.

\section{Acknowledgements}

Authors are thankful to Vice-chancellor and Director of Research \& Dean, P.G.Studies, Navsari Agricultural University, Navsari for providing necessary permissions as well as moral support as and when required. The technical guidance provided by Principal, and help rendered by Dr.A.A.Wagh, Assistant Professor, Van Bandhu Veterinary College, NAU, Navsari is duly acknowledged. A Special thank to Directors of Abhumka Herbal Pvt. Ltd., Ahmedabad for their needful support and providing a product (DudhNahar ${ }^{\circledR}$ ) for the present study.

\section{Competing interests}

Authors declare that they have no competing interest.

\section{References}

1. Savoini, G. and Agazzi, A. (2003) Transition Cow: Nutritional Prophylaxis. Vet. Res. Comm. 27 Suppl. (1): 153156.

2. Mirzaei, F. (2011) Effect of herbal feed additives on performance parameters of ruminants and especially on dairy goat: a Review. Report and Opinion. 3(10): 18-36. (Cited from http://www.sciencepub.net/report), retrieved on 07-08-2012.

3. Mishra, U.K., Kanesh, J.S., Mandal, A.K., Das, R.K., Rayaguru, K. and Parija, S.C. (2006) Potentials of herbal galactogogues in milk production of ruminants. The Indian Cow. July-Sept, 2006: 44-52.

4. Singh, N., Kumari, R., Yadav, R.S., Akbar, M.A. and Sengupta, B.P. (1991) Effect of some commonly used galactagogue on milk production and biogenic amines in buffaloes. Indian Vet. Med. J. 15: 20-24.

5. Baig, M.I. and Bhagwat, V.G. (2009) Study the efficacy of Galactin Vet bolus on milk yield in dairy cows. Vet. World. 2(4): 140-142.

6. Bhatt, N., Singh, M. and Ali, A. (2009) Effect of feeding herbal preparations on milk yield and rumen parameters in lactating crossbred cows. Int. J. Agric. Biol. 11(6): 721-726 (Cited from http://www.fspublishers.org).

7. Qureshi, M.I. (1999) Efficiency of Lectovet as a galactagogue in dairy cattle. Indian Vet. Med. J. 23: 134-136. 
8. Ramesh, P.T., Mitra, S.K., Suryanarayna, T. and Sachan, A. (2000) Evaluation of galactin- a herbal galactogogue preparation in dairy cows. The Veterinarian. 2(4): 1-3.

9. Singhal, S.P. (1995) Study on the effect of feeding Payapro on milk yield in lactating cows. Dairy Guide. 1: 45-47.

10. Gaya, I.B., Okasha, M.A.M., Abubakar, M.S., Maje, M.I. and Adebayo, B.A. (2012) Toxicological and lactogenic studies on the seeds of Hibiscus sabdariffa linn (Malvaceae) extract on serum prolactin levels of albino wistar rats. The Internet Journal of Endocrinology. 5(2): 46-50 (Cited from http://www.ispub.com:80/journal/the-internet-journal-ofendocrinology), retrieved on 07-08-2012.

11. Bharti, S. K., Sharma N. K., Gupta, A. K., Murari, K. and Awanish Kumar. (2012). Pharmacological actions and potential uses of diverse galactogogues in Cattle. International Journal of Pharmacology and Therapeutics. 2(1): 24-28 (Cited from www.earthjournals.org) retrieved on 07-08-2012.

12. Anonymous. (1985). Medicinal Plants of India (Indian Council of Medical Research, New Delhi). P285.

13. Abo El-Nor, S., Khattab, H.A., Al-Alamy, H.A., Salem, F.A. and Abdou, M.M. (2007). Effect of some medicinal plants seeds in rations on the productive performance of lactating buffaloes. Int. J. Dairy Sci. 2(4): 348-355.

14. Anjaria, J.V. and Gupta, I. (1967). Studies on lactogenic property of Leptadenia reticulata (Jivanti) and Leptaden ${ }^{\circledR}$ tablets in goats, sheep, cows and buffaloes. Indian Vet. J. 44: 967-974.

15. Kolte, A.Y., Waghmare, S.P., Mode, S.G. and Handa, A. (2008). Efficacy of indigenous herbal preparation on altered milk $\mathrm{pH}$, somatic cell count and electrolyte profile in subclinical mastitis in cows. Vet. World. 1(8): 239-240.

16. Kumari, R, and Akbar, M.A. (2006). Clinical efficacy of some herbal drugs during indigestion in buffaloes. Buffalo Bull.25:3-6.

17. Patil, A.B. and Kanitkar, U.K. (1969). Asparagus racemosus willd-form Bordi, as a galactogoue in buffaloes. Indian Vet.J. 46: 718-721.

18. Santosh Kumar, Mehla, R.K., Gupta, A.K., Sharma, V., Meena, R.K., Dandi, R.L. and Anand Prakash. (2011). Effect of herbal feed supplement Shatavari (Asparagus racemosus) on milk production and composition in crossbred cows. Indian J.Ani. Sci. 81(4): 420-23.

19. Preciado, A.T., Hernandez, J.R.O., Carranza, A.C., Mora, V.C. and Chavez, G.R. (2011). Use of herbal galactogogue on milk quality and yield. Asian J. Anim. Vet. Adv. 6(3):297-300.

20. Zhang, Q., Y Guo, Ni H. and Wang, C. (2007). Effect of chinese herbal formula heat-stress-releasing on antioxidant function in dairy cows. Front Agric. China. 1: 478-480.

21. Sridhar, N. B. and Bhagwat, V.G. (2007). Study to assess the efficacy and safety of Galactin Vet bolus in lactating dairy cows. Mysore Journal of Agricultural Sciences. 41 (4): 496502.

22. Şekerden, O. (1999). Factors affecting milk composition and changes in milk composition with lactation stages in antolian buffaloes. Turkish Journal of Veterinary and Animal Sciences. 23: 505-510.

23. Mech, A., Dhali, A., Prakash, B. and Rajkhowa, C. (2008). Variation in milk yield and milk composition during the entire lactation period in Mithun cows (Bos frontalis), Livestock Research for rural development. 2(5): 5-7 (Cited from http://www.lrrd.org/lrrd20/5/cont2005.htm) retrieved on 07-08-2012.

24. Anonymous. (1998). ICAR feeding standard-Nutrient requirements of livestock and poultry (ICAR publication). Pp.90.

25. Snedecor, G.W. and Cochran, W.G. (1989). Statistical Methods. Iowa state university press, Ames, Iowa.

26. Dadkhah, M. A. and Yeganehzad, M. (2011). The Effects of extracts of plants (Medicago Sativa, Trigonella Foenum and Carum Carvi) on milk production in dairy cows. Advances in Environmental Biology. 5(10): 3129-3134.

27. Berhane, M. and Singh, V.P. (2002). Effect of feeding of some indigenous galactopoietic feed supplements on performance of crossbred cows. Indian J. Ani. Sci. 72(7): 609-11.

28. Mishra, I.S., Jaiswal, R.S., Bhardwas, R.K., Sharma, R.J., Joshi, Y.P., Mondal, B.C. and Rahal, A. (2008). Effect of feeding shatavari (Asparagus racemosus) on nutrients intake, digestibility and milk production in crossbred lactating cows, In: National Seminar on Emerging Opportunities for Commercialization in dairy. 6-7 Nov, 2008 (NDRI, Karnal, Haryana,India), 186.

29. Tanwar, P.S., Rathore, S.S. and Kumar, Y. (2008).Effect of shatavari (Asparagus recemosus) on milk production in dairy animals. Indian Journal of Animal Research. 42 (3): 232-33.

30. Sawadogo, L. and Houdebine, L.M. (1988). Induction of beta-casein synthesis in mammary gland of rat treated by plant extracts, CR Acad. Sci. Series III. 306 (4): 167-172.

31. Kirtikar, K.R. and Basu, B.D. (1975). Indian Medicinal Plants. New Cannought Place, Dehradun. P288.

32. Gupta, N., Kumar, A. and Tiwari, D.P. (2004). Effect of herbs as feed additive on growth, nutrient utilization in crossbred heifers, In: XI Animal Nutrition Conference. 2-8 April, 2004 (Jabalpur Madhya Pradesh) 128.

33. Khurana, K.L., Kumar, B., Khanna, S. and Manuja, S. (1996). Effect of herbal galactogogue- Payapro on milk yield in lactating buffaloes. Int. J. Anim. Sci. 11:239-240.

34. Singh, V.K., Ali, Z.A. and Siddioui, M.K. (1996). Ethnomedicines in the Bahraich district of Uttar Pradesh, India. Fitoterapia. 67(1): 65-76.

35. Tiwari, S.P., Lal, R., Arora, S.P. and Narang, M.P. (1993). Effect of feeding anifeed - a herbal combination on milk production in crossbred cows. Indian J. Anim. Nutr. 10: 115-117.

36. Ravikumar, B.R. and Bhagwat, V.G. (2008) Study of the influence of Galactin Vet Bolus on milk yield in lactating dairy cows. Livestock Line . 5-7, December, 2008. 